\title{
PERBANDINGAN KOAGULAN HASIL PERCOBAAN DENGAN KOAGULAN KOMERSIAL MENGGUNAKAN METODE JAR TEST
}

\section{Comparison of Experimental and Commercial Coagulants Using Jar Test Method}

\author{
HUSAINI, STEFANUS S. CAHYONO, SUGANAL dan KUKUH N. HIDAYAT \\ Puslitbang Teknologi Mineral dan Batubara \\ Jalan Jend. Sudirman 623 Bandung 40211 \\ Telp. (022) 6030483, Fax. (022) 6003373 \\ e-mail: husaini@tekmira.esdm.go.id
}

\begin{abstract}
ABSTRAK
Polialuminium khlorida (PAC) dan tawas merupakan koagulan yang umum digunakan pada proses pengolahan air limbah. Kedua jenis koagulan tersebut mempunyai sifat yang dapat menarik partikel-partikel lain dalam media air, sehingga berat, ukuran dan bentuknya menjadi semakin besar dan lebih mudah mengendap. PAC adalah garam khusus dari senyawa aluminium klorida yang mampu memberikan daya koagulasi dan flokulasi yang lebih kuat dibandingkan dengan garam-garam aluminium yang biasa seperti aluminium sulfat atau ferri klorida. Puslitbang tekMIRA telah berhasil membuat PAC dan tawas dengan spesifikasi yang memenuhi persyaratan pasar. Kemampuan daya koagulasi dari kedua jenis koagulan tersebut telah dibandingkan dengan koagulan yang biasa digunakan oleh PT Antam di IPAL pengolahan emas Pongkor dengan menggunakan metode jar test. Hasil jar test yang diperoleh menunjukkan bahwa PAC dan tawas hasil penelitian memiliki kemampuan yang lebih baik dibandingkan dengan koagulan yang digunakan di IPAL, PT Antam. Tawas 3 (produk skala laboratorium) dan PAC 11 (produk skala pilot) menunjukkan performa yang paling baik dibandingkan dengan koagulan lainnya termasuk koagulan yang digunakan di IPAL Pengolahan Emas Pongkor. Tawas 3 mampu menurunkan turbidity air limbah (masukan thickener) dari semula sekitar 2000 menjadi 151 NTU (efisiensi penurunan 92,45\%). Hasil ini jauh lebih baik dibandingkan dengan tawas PT Antam yang hanya dapat menurunkan sampai 548 NTU (efisiensi penurunan 72,6\%). Sedangkan untuk PAC hasil percobaan skala pilot yaitu PAC 11 mampu menurunkan turbidity air limbah (dari tailing dump) dari semula 130,74 menjadi 2,92 NTU (efisiensi penurunan 97,77\%); total suspended solid turun dari 196,33 ppm menjadi 38,7 ppm, lebih baik dibandingkan dengan PAC yang digunakan oleh PT Antam yang hanya mampu menurunkan turbidity air limbah sampai 4,67 NTU (efisiensi penurunan 96,43\%). Adapun total suspended solid turun dari 196,33 menjadi 30,67 ppm.
\end{abstract}

Kata kunci: polialuminium khlorida (PAC), tawas, koagulan, instalasi pengolahan air limbah (IPAL), jar test.

\begin{abstract}
PAC and alum are coagulants generally used for waste water treatment process. Both coagulants have properties that can attract particles so their weight, size and shape become larger and easier to precipitate. PAC is a special salt of aluminum chloride which is capable of providing coagulation and flocculation power that are more powerful than that of regular aluminum and iron salts such as aluminum sulfate or ferric chloride. Research and Development Center for Mineral and Coal Technology had successfully prepared specified PAC and alum that fulfill the market requirement. The coagulating power of both coagulants have been comparred to the coagulant usually used by PT Antam for waste water treatment in the WWTP, Pongkor,
\end{abstract}


using jar test method. Jar test results showed that PAC and alum had better ability than that of the coagulant used in WWTP, PT Antam. Alum no. 3 (the product of laboratorium experiment) and PAC no. 11 (product of pilot experiment) show best performance than other coagulants. Alum no. 3 can lower waste water turbidity (thickener input) from about 2000 to 151 NTU (reduction efficiency of 92.45\%), better than PT Antam Alum which reduced the waste water turbidity to 548 NTU (reduction efficiency of $72.60 \%$ ). PAC 11 can lower the waste water turbidity from about 130.74 to 2.92 NTU (removal efficiency of 97.77), better than PAC used by PT Antam which can only reduce waste water turbidity to 4.67 NTU (removal efficiency of $96.43 \%$ ).

Keyword: polyaluminum chloride (PAC), alum, coagulant, waste water treatment plant (WWTP), jar test.

\section{PENDAHULUAN}

Koagulasi adalah suatu proses pengubahan partikel koloid menjadi flok yang berukuran lebih besar dan penyerapan bahan organik terlarut pada flok tersebut sehingga pengotor yang ada dalam air dapat dipisahkan melalui proses penyaringan padat-cair (Haydar dan Aziz, 2009). Koagulasi terdiri dari tiga tahapan proses, yaitu pembentukan inti flok, destabilisasi koloid/partikel, dan pembesaran ukuran partikel. Prinsip tersebut banyak diterapkan dalam proses pengolahan air limbah (Altenor dan Gaspard, 2014). Ada beberapa bahan kimia yang umum digunakan dalam proses pengolahan air limbah antara lain PAC (Polyaluminium Chloride) dan tawas. Kedua jenis bahan kimia tersebut mempunyai kemampuan untuk menjernihkan air dengan cara mengkoagulasi zat-zat tersuspensi atau dispersi koloid dalam air, menghasilkan flok yang lebih besar, sehingga dapat membantu terjadinya pengendapan dengan cepat (Margaretha $d k k ., 2012)$. Namun secara umum, PAC lebih disukai daripada tawas bila diharapkan ukuran flok yang lebih besar dan kecepatan pengendapan yang lebih tinggi.

PAC dengan rumus kimia $\mathrm{Al}_{n}(\mathrm{OH})_{\mathrm{m}} \mathrm{Cl}(3 n-m) x$ merupakan suatu persenyawaan anorganik komplek, ion hidroksil serta ion alumunium bertahap klorinasi yang berlainan sebagai pembentuk polinuklir (Wang dkk., 2014). Apabila mengalami hidrolisis (penguraian karena air), akan terbentuk spesi monomer dan polymer yang terpenting yaitu kation dari $\mathrm{Al}_{13} \mathrm{O}_{4}(\mathrm{OH})_{24}{ }^{7+}$ dan yang dianggap kurang penting yaitu $\mathrm{Al} 8(\mathrm{OH})_{20}{ }^{4+}$. Koagulan-koagulan terpolimerisasi terdiri dari: polyaluminium chloride (PACl) dan polyaluminium chlorohydrate (PACH). Dalam praktek, ada sedikit perbedaan kinerja antara $\mathrm{PACH}$ dan $\mathrm{PACl}$ dalam aplikasi pengolahan air, walaupun PACH lebih terhidrasi (hydrated). Koagulan polialuminium secara umum mengkonsumsi tingkat alkalinitas yang lebih kecil dibandingkan dengan alum (Nansubuga $\left.d k k_{.}, 2013\right)$. PACl efektif pada selang $\mathrm{pH}$ yang lebih lebar dibandingkan dengan alum dan hasil penelitian menunjukkan bahwa $\mathrm{PACl}$ bekerja dengan baik pada rentang $\mathrm{pH}$ antara 5,0-8,0 (Gebbie, 2001).

Bahan kimia PAC dapat dibuat melalui beberapa tahapan proses yaitu preparasi, pencampuran dan pelarutan, pengendapan dan penyaringan serta pengeringan. Preparasi merupakan tahapan penyiapan bahan baku yang meliputi alumina trihidrat $\mathrm{Al}(\mathrm{OH})_{3}$, asam klorida $(\mathrm{HCl})$, asam sulfat $\left(\mathrm{H}_{2} \mathrm{SO}_{4}\right)$, dan kalsium karbonat $\left(\mathrm{CaCO}_{3}\right)$. Pada tahap pelarutan, $\mathrm{Al}(\mathrm{OH})_{3}$ direaksikan dengan $\mathrm{HCl}$ sambil diaduk dan dipanaskan pada suhu mendidih $\left(100-110^{\circ} \mathrm{C}\right)$ selama 90 menit. Sisa Al yang tidak larut direaksikan dengan asam sulfat berlebih. Kelebihan asam sulfat tersebut direaksikan dengan $\mathrm{CaCO}_{3}$ untuk menaikkan basisitas (Water New Zealand, 2013), sehingga kandungan sulfat dalam larutan PAC dapat ditekan sekecil mungkin, karena sulfat merupakan pengotor yang dapat menurunkan mutu PAC (Husaini $d k k .$, 2016) Produk yang dihasilkan dari reaksi-reaksi tersebut, selain PAC cair juga terbentuk gipsum $\left(\mathrm{CaSO}_{4} .2 \mathrm{H}_{2} \mathrm{O}\right)$ berupa endapan yang selanjutnya difiltrasi. Adapun reaksi kimia yang terjadi dalam pembuatan PAC adalah sebagai berikut: (Zhou $d k k ., 2014)$

$$
\begin{aligned}
& 4 \mathrm{Al}(\mathrm{OH})_{3}+12 \mathrm{HCl} \rightarrow 4 \mathrm{AlCl}_{3}+12 \mathrm{H}_{2} \mathrm{O} \\
& 4 \mathrm{Al}(\mathrm{OH})_{3}+6 \mathrm{H}_{2} \mathrm{SO}_{4} \rightarrow 2 \mathrm{Al}_{2}\left(\mathrm{SO}_{4}\right)_{3}+12 \mathrm{H}_{2} \mathrm{O} \\
& 4 \mathrm{AlCl}_{3}+2 \mathrm{Al}_{2}\left(\mathrm{SO}_{4}\right)_{3}+\mathrm{CaCO}_{3}+24 \mathrm{H}_{2} \mathrm{O} \rightarrow \\
& \mathrm{CaSO}_{4} .2 \mathrm{H}_{2} \mathrm{O}+\mathrm{CO}_{2}+\mathrm{H}_{2} \mathrm{O}+\mathrm{PAC} \\
& 8 \mathrm{Al}(\mathrm{OH})_{3}+2 \mathrm{H}_{2} \mathrm{SO}_{4}+10 \mathrm{HCl}+\mathrm{CaCO}_{3} \rightarrow \\
& \mathrm{Al}_{8}(\mathrm{OH})_{12}\left(\mathrm{SO}_{4}\right) \mathrm{Cl}_{10}+\mathrm{CO}_{2}+\mathrm{CaSO}_{4} 2 \mathrm{H}_{2} \mathrm{O} \\
& +11 \mathrm{H}_{2} \mathrm{O}
\end{aligned}
$$

Campuran berbentuk sluri yang dihasilkan diendapkan dan disaring untuk mendapatkan 
PAC cair jernih yang sudah terpisah dari gipsum. PAC cair dapat dikeringkan dalam spray drier menghasilkan PAC bubuk, sedangkan padatan gipsum basah dikeringkan dalam pengering menghasilkan gipsum kering. Bila dikehendaki konsentrasi tertentu, PAC dapat diencerkan sampai konsentrasi tertentu sesuai dengan spesifikasi yang dikehendaki.

Tawas merupakan kristal putih yang berbentuk gelatin dan mempunyai sifat yang dapat menarik partikel - partikel lain sehingga berat, ukuran dan bentuknya menjadi semakin besar dan mudah mengendap (Burgess dkk., 2015). Tawas merupakan nama lain dari alumunium sulfat yang memiliki rumus kimia $\mathrm{Al}_{2}\left(\mathrm{SO}_{4}\right)_{3}$. Tawas dapat digunakan untuk penjernihan air, melalui proses penggumpalan (koagulasiflokulasi) padatan - padatan terlarut maupun tersuspensi di dalam air, sehingga dapat digunakan untuk pembersihan air sumur, sebagai bahan kosmetik, zat warna tertentu dan zat penyamak kulit (Zouboulis dan Tzoupanos, 2010). Reaksi kimia yang terjadi antara aluminium oksida pada bauksit dengan asam sulfat dalam proses pembuatan tawas adalah sebagai berikut :

$$
\begin{aligned}
\mathrm{Al}_{2} \mathrm{O}_{3}+3 \mathrm{H}_{2} \mathrm{SO}_{4} & \rightarrow \mathrm{Al}_{2}\left(\mathrm{SO}_{4}\right)_{3}+3 \mathrm{H}_{2} \mathrm{O} \\
\Delta \mathrm{G}_{0} & =-147,17 \mathrm{kkal} / \mathrm{mol} \\
\mathrm{Fe}_{2} \mathrm{O}_{3}+3 \mathrm{H}_{2} \mathrm{SO}_{4} & \rightarrow \mathrm{Fe}_{2}\left(\mathrm{SO}_{4}\right)_{3}+3 \mathrm{H}_{2} \mathrm{O} \\
\Delta \mathrm{G}_{0} & =-138,75 \mathrm{kkal} / \mathrm{mol}
\end{aligned}
$$

Tidak hanya untuk pengolahan limbah industri, PAC dan tawas juga digunakan untuk pengolahan air limbah domestik di kota - kota besar serta lokasi-lokasi yang tercemar (Albert, 2010). Selain itu, kedua jenis koagulan tersebut juga digunakan untuk mengolah air bersih, karena air bersih merupakan sumber daya alam yang jumlahnya terbatas sehingga perlu dikelola dengan baik seiring dengan meningkatnya jumlah populasi manusia dan perkembangan industri (Wang $d k k ., 2014)$.

PT Antam Tbk UBPE (Unit Bisnis Penambangan Emas) Pongkor menghasilkan limbah berupa slurry yang berasal dari proses sianidasi bijih emas. Limbah tersebut keluar dari alat thickener seperti terlihat pada Flow sheet pengolahan emas pada Gambar 1 .

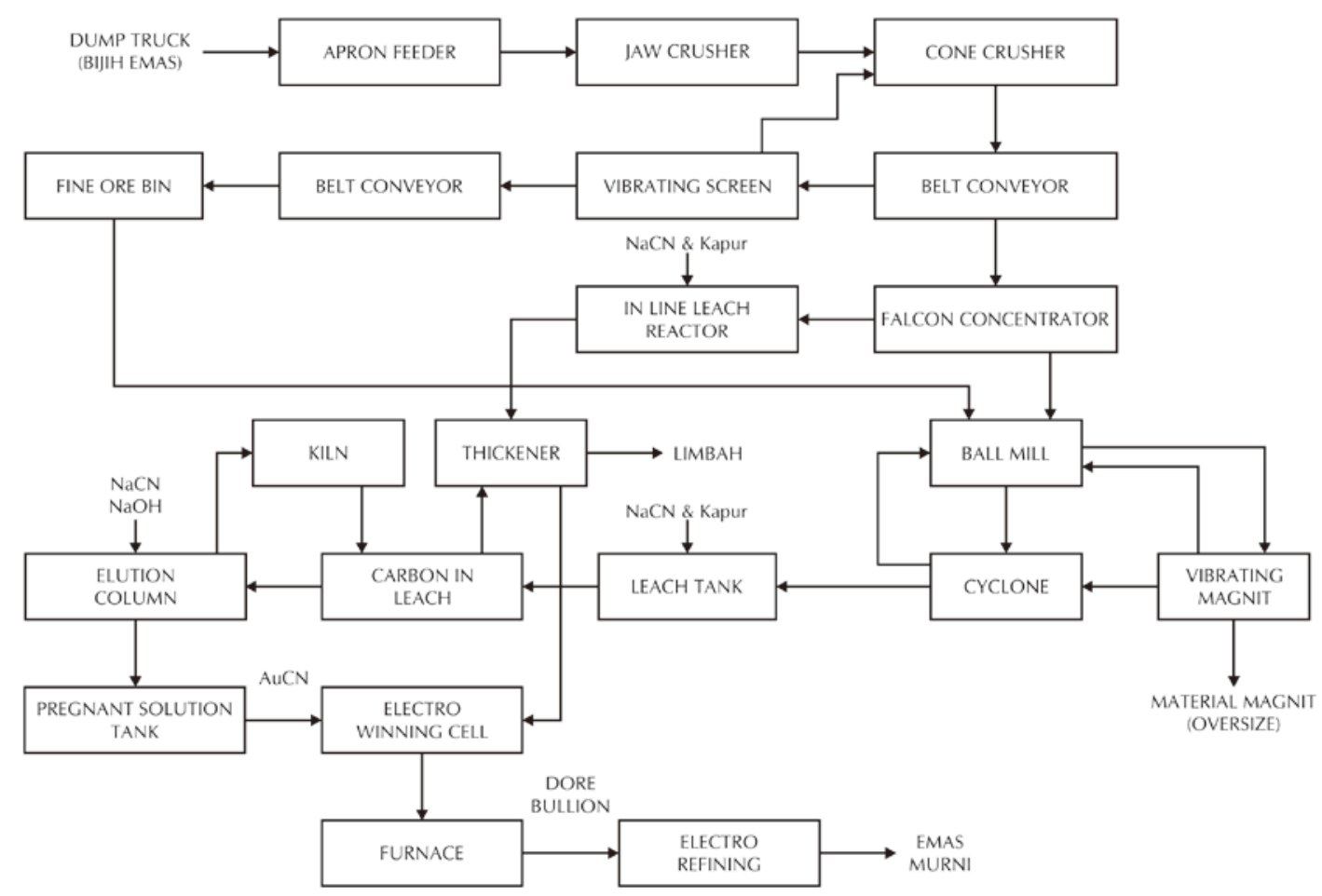

Gambar 1. Flow sheet pengolahan emas Pongkor 
Limbah sluri tersebut dialirkan ke thickener sambil ditambahkan flokulan (PAC/tawas). Aliran bawah (under flow) thickener ini masuk ke tanki cyanide detoxification untuk menurunkan kandungan sianida dengan menambahkan natrium meta-bisulfit $\left(\mathrm{Na}_{2} \mathrm{~S}_{2} \mathrm{O}_{5}\right)$. Hasil reaksinya dialirkan ke dalam tailing silo: $60 \%$ berat sluri dari tailing silo dimasukkan ke bekas lubang tambang, sedangkan yang $40 \%$ masuk ke tailing damp. Dari tailing damp ini limbah dipompa ke instalasi pengolahan air limbah (IPAL) untuk menurunkan kekeruhan (turbidity) nya melalui peralatan settling tank, effluent tank dan decant tank, dan akhirnya dibuang ke sungai. Settling tank adalah tempat penambahan koagulan (PAC) agar terjadi proses koagulasi dan effluent tank adalah tempat proses flokulasi (pembesaran flok) terjadi dan decant tank adalah tempat untuk pemisahan padatan (berbentuk flok) dari cairan limbah terolah sebelum dibuang ke sungai (lihat Gambar 2). PT Antam Tbk UBPE Pongkor selama ini menggunakan koagulan jenis poly alumunium chloride (PAC) dan flokulan jenis anionic floculant untuk menurunkan tingkat kekeruhan maupun total suspended solids (TSS) di instalasi IPAL-nya. Air hasil olahan dengan IPAL tersebut telah berkurang kekeruhannya dan sudah memenuhi baku mutu limbah buangan industri dan di recycle ke pabrik pengolahan sebagai fresh water untuk kebutuhan air di dalam pabrik dan air backfilling serta pengeboran di dalam tambang dan sebagian dibuang ke sungai Cimanganten (Gambar 2).

Ada dua macam studi perbandingan yaitu 1) membandingkan koagulan (tawas dan PAC) hasil percobaan laboratorium di laboratorium Puslitbang tekMIRA dengan tawas yang dipakai PT. Antam untuk mengolah limbah pengolahan emas Pongkor yang dialirkan ke thickener (sebelum dibuang ke tailing pond) sebagai tahap koagulasi awal dan 2) membandingkan koagulan (PAC hasil percobaan pilot plant di Cipatat) dengan koagulan yang dipakai PT. Antam untuk mengolah limbah hasil sianidasi bijih emas Pongkor yang sudah mengalami pengendapan di tailing damp sebagai tahap koagulasi akhir.

Tujuan penelitian ini adalah untuk membandingkan PAC dan tawas hasil penelitian Puslitbang tekMIRA dengan koagulan yang digunakan di PT Antam dengan metode jar test.

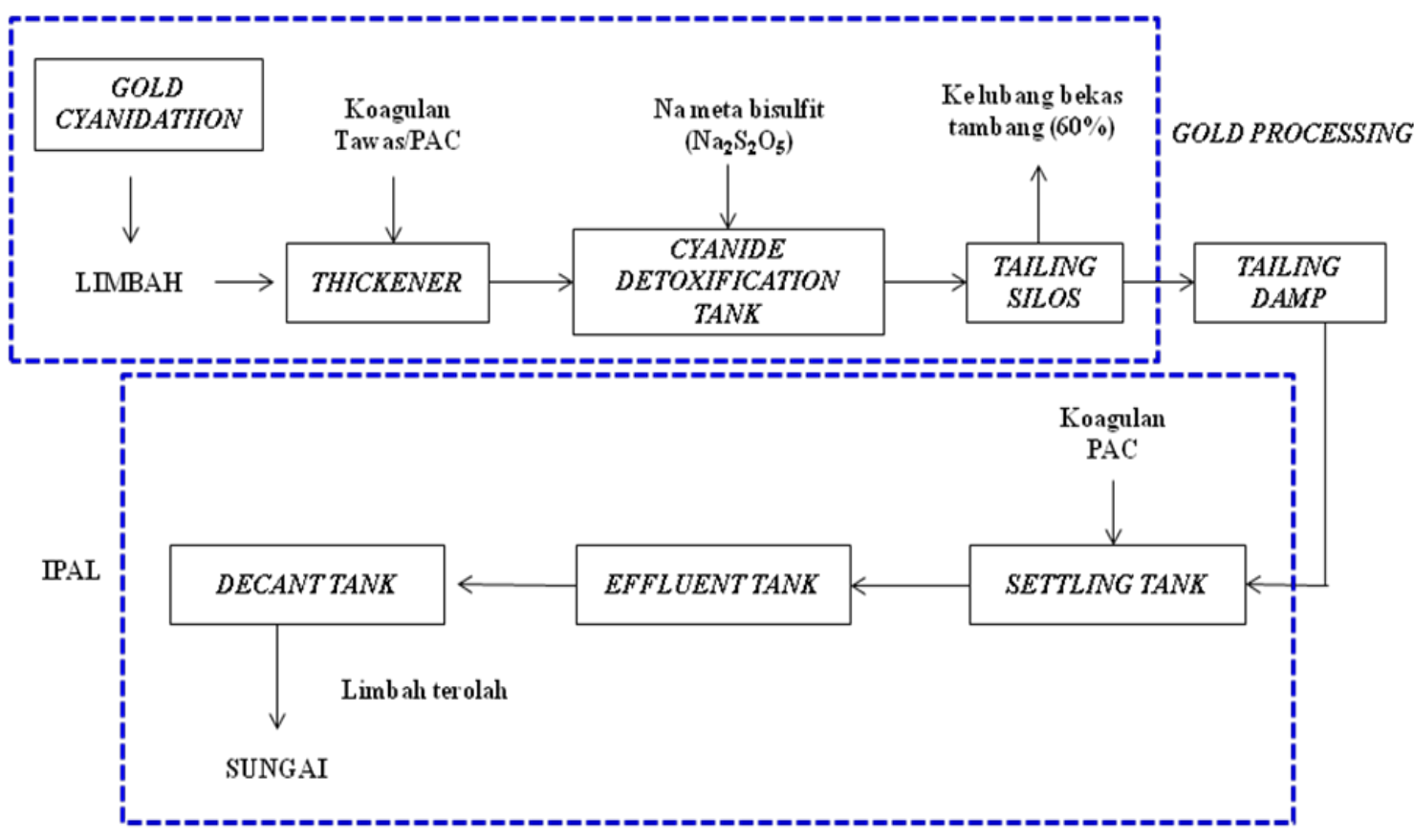

Gambar 2. Bagan alir pengolahan limbah emas Pongkor 


\section{METODE}

Jar test adalah suatu metode pengujian untuk mengetahui kemampuan suatu koagulan dan menentukan kondisi operasi (dosis) optimum pada proses penjernihan air dan air limbah. Besaran yang diukur dan dicatat dalam jar test ini meliputi $\mathrm{pH}$ air limbah, TSS dan kekeruhannya serta dosis penambahan koagulan untuk volume air limbah tertentu, sehingga dapat diketahui jumlah kebutuhan koagulan dalam pengolahan air limbah yang sebenarnya. Metode jar test mensimulasikan proses koagulasi dan flokulasi untuk menghilangkan padatan tersuspensi (suspended solid) dan zat-zat organik yang dapat menyebabkan masalah kekeruhan, bau dan rasa.

Apabila percobaan dilakukan secara tepat, informasi yang berguna akan diperoleh untuk membantu operator IPAL dalam mengoptimalkan proses-proses koagulasi, flokulasi dan penjernihan. Jar test memberikan data mengenai kondisi optimum untuk parameter-parameter proses seperti: dosis koagulan dan koagulan pembantu, $\mathrm{pH}$, metode pembubuhan bahan kimia, kecepatan aliran larutan kimia, waktu dan intensitas pengadukan cepat (koagulasi) dan pengadukan lambat (flokulasi) serta waktu penjernihan.

Jar test dilakukan untuk membandingkan PAC dan tawas hasil penelitian Puslitbang tekMIRA skala laboratorium dan PAC skala pilot. PAC dan tawas dari Puslitbang tekMIRA yang akan diuji dalam jar test ini dibuat dari bahan dasar alumina tri hidrat (ATH) baik untuk skala laboratorium maupun pilot. Lokasi pengujian dilakukan di Instalasi Pengolahan Air Limbah (IPAL) PT Antam Tbk UBPE Pongkor.

Untuk mengukur kekeruhan air dan nilai $\mathrm{pH}$ dari suatu air baku tertentu menggunakan beberapa gelas beaker yang telah diberi label.

\section{Prosedur Jar Test}

Untuk koagulan hasil percobaan skala laboratorium, Jar test dilakukan 2 kali dengan menggunakan dosis koagulan yang berbeda, yaitu tawas padat dengan dosis $373 \mathrm{mg}$ per L air limbah $(0,373 \mathrm{~g} / \mathrm{L})$ dan $745 \mathrm{mg}$ per $\mathrm{L}$ air limbah $(0,745 \mathrm{~g} / \mathrm{L})$.
1. Larutan tawas disiapkan dengan kondisi sebagai berikut:

a. tawas padat sebanyak $15 \mathrm{~g}$ dimasukkan ke dalam gelas lalu ditambahkan air sebanyak 500 gram kemudian diaduk sampai larut sempurna (konsentrasi $\mathrm{Al}_{2} \mathrm{O}_{3}$ dalam larutan tawas 0,52\%).

b. limbah sluri sebanyak $500 \mathrm{ml}$ diambil dari masukan thickener, dimasukkan ke dalam beaker glass, kemudian tambahkan 6,21 gram larutan tawas (mengandung 0,186 gram tawas padat) (untuk mendapatkan dosis tawas padat sekitar 0,373g per L air limbah) lalu aduk campuran secara cepat. Dengan cara yang sama untuk dosis tawas padat sebesar 0,745 gram per L air limbah, larutan tawas sebanyak 12,42 g dimasukkan ke dalam beaker glass yang berisi $500 \mathrm{ml}$ air limbah lalu campuran tersebut diaduk secara cepat.

c. Amati secara visual dan dicatat laju pengendapan flok yang terbentuk serta diukur kekeruhan dan TSS-nya

d. Jar test dilakukan sebanyak 3 kali dengan menggunakan tawas yang berbeda (Tawas 1, Tawas 2, Tawas 3) dengan komposisi yang berbeda seperti yang tercantum pada Tabel 1.

2. Larutan PAC disiapkan dengan kondisi sebagai berikut :

PAC Cair (komposisi terlihat dalam Tabel 2) dengan dosis $200 \mathrm{mg}$ per $\mathrm{L}$ air limbah $(0,2 \mathrm{~g} / \mathrm{L})$ dan $400 \mathrm{mg}$ per $\mathrm{L}$ air limbah $(0,4$ $\mathrm{g} / \mathrm{L})$.

a. limbah sluri (diambil dari masukan thickener) sebanyak $500 \mathrm{~mL}$ dimasukkan ke dalam beaker glass.

b. 0,37 gram PAC cair dimasukkan ke dalam beaker glass yang berisi 500 gram air limbah (untuk mendapatkan dosis PAC sekitar 0,2 g per $\mathrm{L}$ air limbah) lalu diaduk secara cepat. Dengan cara yang sama untuk dosis PAC sebesar 0,4 gram per $\mathrm{L}$ air limbah, larutan PAC sebanyak 0,74 gram dimasukkan ke dalam beaker glass yang berisi $500 \mathrm{ml}$ air limbah lalu campuran tersebut diaduk secara cepat.

c. Dilakukan pengamatan laju pengendapan flok yang terbentuk, serta diukur kekeruhan dan TSS-nya. Koagulan yang diuji pada jar test ini dibedakan atas PAC, tawas hasil percobaan skala laboratorium dan PAC 
hasil percobaan skala pilot yang merupakan hasil penelitian tekMIRA, dibandingkan dengan tawas dan PAC yang digunakan oleh PT Antam. Komposisi masing-masing koagulan dapat dilihat pada Tabel 1 sampai dengan Tabel 3.

d. Jar test PAC hasil skala pilot dilakukan dengan kondisi sebagaimana terlihat pada Tabel 4.

Jar Test dimulai dengan membandingkan PAC tekMIRA dengan PAC yang biasa digunakan oleh PT Antam dengan dosis yang sama.
Dosis koagulan curah yang dibutuhkan di lapangan yaitu 0,76 kg/ton limbah (0,76 g/L). Oleh karena itu, dosis awal yang digunakan untuk Jar Test ini adalah 0,76 g per liter limbah.

Kemudian dosis PAC diturunkan untuk mengetahui jumlah dosis yang optimal. Selanjutnya jar test dilakukan dengan menggunakan beberapa macam koagulan/ flokulan untuk melihat pengaruh dosis dan jenis koagulan/flokulan tersebut terhadap kekeruhan dan TSS dalam air terolah.

Tabel 1. Komposisi kimia tawas padat skala laboratorium

\begin{tabular}{ccccc}
\hline Komponen & Tawas 1 & Tawas 2 & Tawas 3 & Tawas Antam \\
\hline $\mathrm{Al}_{2} \mathrm{O}_{3}(\%)$ & 15,81 & 15,50 & 17,73 & 17,73 \\
$\mathrm{SO}_{4}(\%)$ & 7,48 & 7,71 & 10,98 & 10,30 \\
$\mathrm{H}_{2} \mathrm{O}(\%)$ & 16,84 & 17,56 & 12,96 & 12,96 \\
\hline
\end{tabular}

Catatan: $\mathrm{H}_{2} \mathrm{O}$ dihitung dengan rumus: $\left[\mathrm{BM} \mathrm{Al}_{2} \mathrm{O}_{3} /\left(\mathrm{BM} \mathrm{Al}_{2}\left(\mathrm{SO}_{4}\right)_{3} \times \mathrm{H}_{2} \mathrm{O}\right]\right.$

Tabel 2. Komposisi kimia PAC cair skala laboratorium

\begin{tabular}{cccc}
\hline Komponen & PAC 1 & PAC 2 & PAC 3 \\
\hline Kadar $\mathrm{Al}_{2} \mathrm{O}_{3}(\%)$ & 12,58 & 12,62 & 9,58 \\
Kadar $\mathrm{Cl}(\%)$ & 14,25 & 12,80 & 11,90 \\
Kadar $\mathrm{SO}_{4}(\%)$ & 8,50 & 6,33 & 3,92 \\
Berat jenis & 1,244 & 1,246 & 1,210 \\
pH larutan & 1,310 & 1,566 & 1,790 \\
\hline
\end{tabular}

Tabel 3. Komposisi kimia PAC cair skala pilot

\begin{tabular}{cccc}
\hline Komponen & PAC-9 & PAC-10 & PAC-11 \\
\hline Kadar $\mathrm{Al}_{2} \mathrm{O}_{3}(\%)$ & 10,85 & 11,43 & 12,57 \\
Kadar $\mathrm{Cl}^{-}(\%)$ & 11,24 & 12,70 & 12,00 \\
Kadar sulfat (\%) & 3,44 & 2,66 & 3,62 \\
Berat jenis & 1,242 & 1,242 & 1,244 \\
pH larutan & 1,66 & 1,766 & 1,868 \\
\hline
\end{tabular}

Tabel 4. Kondisi Jar Test untuk koagulan hasil percobaan skala pilot

\begin{tabular}{ll}
\hline & Volume limbah : 1 liter \\
& TSS limbah rerata: 196,33 g/L \\
Kondisi jar & Kekeruhan rerata: 130,74 NTU \\
test: & Waktu aduk cepat : 2 menit \\
& Waktu aduk lambat : 5 menit \\
& Waktu pengendapan : 1 jam \\
\hline
\end{tabular}




\section{HASIL DAN PEMBAHASAN}

\section{Hasil Jar Test Tawas dan PAC Skala Laboratorium}

Jar Test dilaksanakan sebanyak dua kali untuk menguji kualitas tawas dan PAC hasil percobaan di Pabrik Pengolahan Emas Pongkor milik PT Aneka Tambang. Jar Test dlakukan untuk mengetahui dosis yang dibutuhkan dalam pengolahan air limbah hasil pengolahan emas. Limbah pengolahan emas yang digunakan adalah masukan (input) limbah berbentuk sluri ke thickener sebelum masuk ke cyanide detoxification tank (lihat Gambar 2). Komposisi kimia tawas dan PAC yang digunakan untuk Jar Test masing-masing dapat dilihat pada Tabel 1 dan 2 .

Setelah dilakukan Jar Test sesuai dengan prosedur uji, diperoleh hasil pengujian yang dapat dilihat pada Tabel 5 dan 6 .

Dari Tabel 5 terlihat bahwa Tawas 3 dapat memberikan turbidity air limbah terolah terkecil yaitu sebesar 151 NTU dengan menggunakan air limbah asal yang memiliki turbidity sekitar $2000 \mathrm{NTU}$. Hal ini dapat dipahami karena kandungan $\mathrm{Al}_{2} \mathrm{O}_{3}$ dalam Tawas 3 paling tinggi dibandingkan dengan Tawas 1 dan Tawas 2 yaitu 17,73\%. Tawas 3 memberikan nilai $\mathrm{pH}$ dalam air limbah terolah paling kecil dibandingkan dengan jenis yang lainnya, karena kadar sulfat dalam tawas 3 lebih besar yaitu 10,98\% dibandingkan dengan tawas 1 dan tawas 2 yang masingmasing mengandung sulfat $7,48 \%$ dan $7,71 \%$. Jika dibandingkan dengan tawas milik Antam yang memberikan turbidity air limbah terolah 548 NTU pada pH 8,83, Tawas 3 memiliki kemampuan yang jauh lebih baik dalam hal penngolahan air limbah. Sedangkan penambahan untuk PAC, PAC 21 memiliki kemampuan yang paling baik di antara koagulan yang lainnya. PAC 21 dapat menurunkan turbidity air limbah dari 2000 NTU menjadi 59 NTU pada $\mathrm{pH} 8,85$. Tawas 3 memiliki komposisi kimia 17,73 \% $\mathrm{Al}_{2} \mathrm{O}_{3}$, $10,98 \% \quad \mathrm{SO}_{4}$ dan $12,96 \% \mathrm{H}_{2} \mathrm{O}$. Sedangkan PAC 21 memiliki komposisi kimia 12,62\% $\mathrm{Al}_{2} \mathrm{O}_{3}, 12,8 \% \mathrm{Cl}$ dan $6,33 \% \mathrm{SO}_{4}{ }^{2-}$. Keefektifan tawas dan PAC ini diakibatkan oleh kemampuan ion $\mathrm{Al}$ bermuatan positif yang dapat menarik partikel-partikel koloid bermuatan negatif yang terjadi pada rentang pH 5 hingga 8 (Mose, 2014).

Tabel 6 menunjukkan hasil Jar Test dengan menggunakan dosis 4 kali lebih banyak dibandingkan dengan percobaan sebelumnya. Hasil yang diperoleh menunjukkan bahwa dengan menggunakan dosis yang lebih banyak, nilai turbidity air terolah akan lebih kecil. Hal ini mudah dimengerti bahwa dengan tingginya kandungan ion Al yang ditambahkan ke dalam limbah sampai batas tertentu, akan menarik partikel-partikel koloid yang lebih banyak. Namun apabila dosis berlebihan, akan menaikkan turbidity air limbah terolah, hal ini dapat dilihat pada PAC21 dengan dosis 800 ppm. Koagulan terbaik pada percobaan ini adalah PAC 20 dengan nilai turbidity air limbah terolah sampai 26 NTU pada $\mathrm{pH}$ 8,6. Grafik pada Gambar 3 menunjukkan perbandingan hasil jar test pengolahan air limbah input thickener dengan menggunakan dua dosis yang berbeda. Koagulan yang menunjukkan penurunan turbidity yang signifikan adalah Tawas 1 dilanjutkan dengan Tawas Antam, PAC 22, Tawas 2, PAC 20, Tawas 3 dan PAC 21. Terlihat bahwa tingkat penurunan turbidity air olahan tidak sama yang berarti jumlah dosis optimal masing-masing jenis koagulan berbeda antara satu dan yang lainnya. Koagulan yang memiliki kualitas bagus adalah koagulan yang mampu menurunkan turbidity air limbah sekecil mungkin dengan dosis yang rendah sehingga ekonomis. Seperti hasil penelitian Rusdi, Sidi dan Pratama, (2014), dengan menambahkan dosis tawas sebanyak $20 \mathrm{mg} / \mathrm{l}$ mampu menurunkan turbidity sebesar 93,44\%.

Grafik pada Gambar 3 merupakan perbandingan persentase penurunan turbidity air olahan dengan menggunakan dosis yang berbeda. PAC 22 menunjukkan penurunan yang paling signifikan yaitu 98,4\%, sebaliknya terjadi pada PAC 21 yang hanya mampu menurunkan nilai turbidity sebesar 97,85\%.

Nilai $\mathrm{pH}$ pada koagulan yang digunakan berkisar antara 8 - 9. Semakin besar dosis koagulan yang digunakan, $\mathrm{pH}$ air olahan semakin kecil. Pengolahan air dengan Tawas 1 menghasilkan air terolah dengan $\mathrm{pH}$ yang tertinggi yaitu 9,04. Sebaliknya $\mathrm{pH}$ air terolah terendah diperoleh dengan menggunakan koagulan Tawas 3 dan PAC 22. 
Tabel 5. Hasil pengujian tawas padat (dosis koagulan A1 =0,373 g/L) dan PAC Cair (dosis koagulan A2 $=0,2 \mathrm{~g} / \mathrm{L}$ )

\begin{tabular}{|c|c|c|c|c|c|c|c|}
\hline Parameter Pengujian & $\begin{array}{l}\text { Tawas } \\
\text { Antam }\end{array}$ & Tawas 1 & Tawas 2 & Tawas 3 & PAC 20 & PAC 21 & PAC 22 \\
\hline Volume air limbah (ml) & 500 & 500 & 500 & 500 & 500 & 500 & 500 \\
\hline Volume koagulan cair (ml) & 6,2 & 6,2 & 6,2 & 6,2 & 0,3 & 0,3 & 0,3 \\
\hline Berat koagulan padat (g) & 0,186 & 0,186 & 0,186 & 0,186 & 0,1 & 0,1 & 0,1 \\
\hline Berat koagulan cair (g) & 6,277 & 6,277 & 6,277 & 6,277 & 0,37 & 0,37 & 0,37 \\
\hline $\begin{array}{l}\text { Waktu untuk kejernihan air sampai } \\
\text { volume } 100 \mathrm{ml}\end{array}$ & 06' 02" & $05^{\prime}$ & $05^{\prime} 14^{\prime \prime}$ & 06 & $05^{\prime} 22^{\prime \prime}$ & 05' 15" & $05^{\prime} 12^{\prime \prime}$ \\
\hline $\mathrm{pH}$ & 8,83 & 9,04 & 8,77 & 8,71 & 8,80 & 8,85 & 8,72 \\
\hline Turbidity limbah terolah (NTU) & 548 & 747 & 266 & 151 & 163 & 59 & 207 \\
\hline Turbidity limbah awal (NTU) & 2000 & 2000 & 2000 & 2000 & 2000 & 2000 & 2000 \\
\hline Efisiensi penurunan turbidity (\%) & 72,6 & 62,65 & 86,7 & 92,45 & 91,85 & 97,05 & 89,65 \\
\hline
\end{tabular}

Tabel 6. Hasil pengujian tawas padat (dosis koagulan B1 =0,745 g/L) dan PAC Cair (dosis koagulan B2 $=0,4 \mathrm{~g} / \mathrm{L}$ )

\begin{tabular}{cccccccc}
\hline Parameter Pengujian & $\begin{array}{c}\text { Tawas } \\
\text { Antam }\end{array}$ & Tawas 1 & Tawas 2 & Tawas 3 & PAC 20 & PAC 21 & PAC 22 \\
\hline Volume air limbah (ml) & 500 & 500 & 500 & 500 & 500 & 500 & 500 \\
Volume koagulan cair (ml) & 12,42 & 12,42 & 12,42 & 12,42 & 0,6 & 0,6 & 0,6 \\
Berat koagulan padat (g) & 0,373 & 0,373 & 0,373 & 0,373 & 0,2 & 0,2 & 0,2 \\
Berat koagulan cair (g) & 12,554 & 12,554 & 12,554 & 12,554 & 0,74 & 0,74 & 0,74 \\
Waktu untuk kejernihan air sampai & $06^{\prime} 52^{\prime \prime}$ & $06^{\prime} 32^{\prime \prime}$ & $06^{\prime} 34^{\prime \prime}$ & $06^{\prime} 58^{\prime \prime}$ & $05^{\prime} 57^{\prime \prime}$ & $05^{\prime} 37^{\prime \prime}$ & $06^{\prime} 05^{\prime \prime}$ \\
volume 100 ml & & & & & & & \\
pH & 8,45 & 8,56 & 8,45 & 8,48 & 8,46 & 8,49 & 8,38 \\
Turbidity limbah terolah (NTU) & 110 & 111 & 98 & 62 & 26 & 43 & 32 \\
Turbidity limbah awal (NTU) & 2000 & 2000 & 2000 & 2000 & 2000 & 2000 & 2000 \\
Efisiensi penurunan turbidity(\%) & 94,5 & 94,45 & 95,1 & 96,9 & 98,7 & 97,85 & 98,4 \\
\hline
\end{tabular}

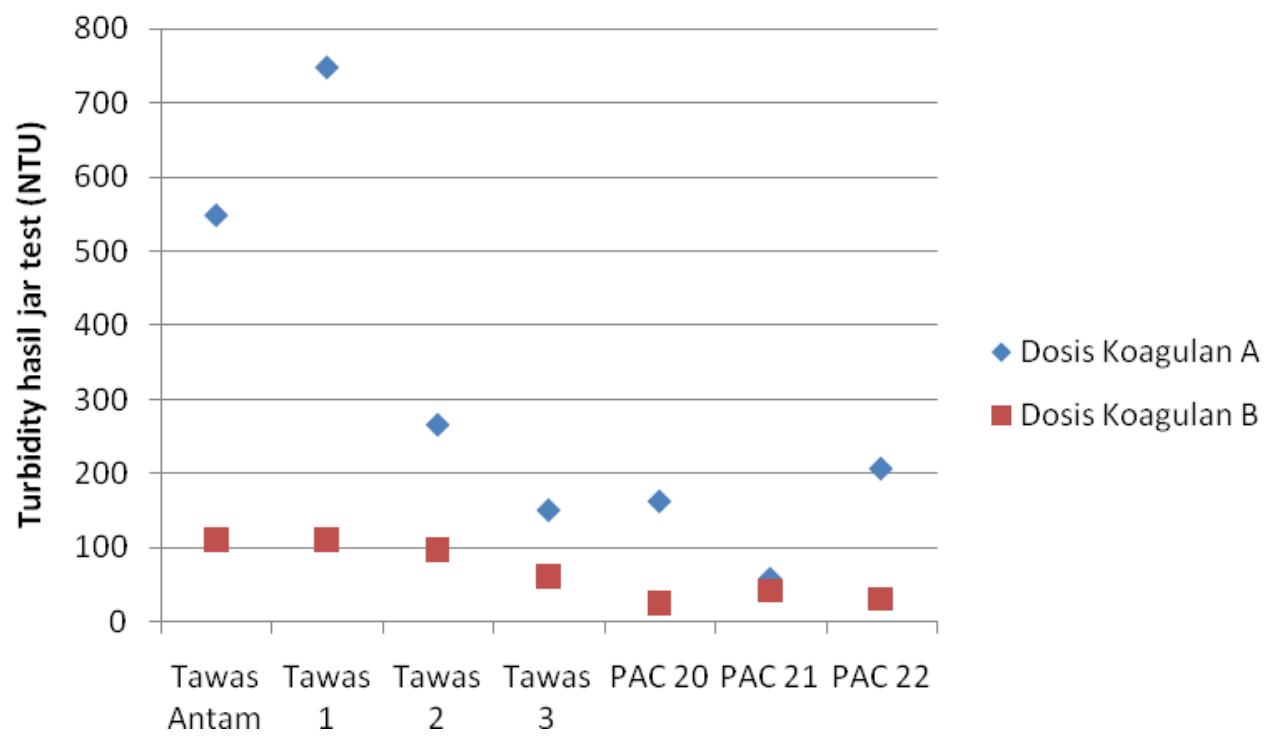

Gambar 3. Perbandingan turbidity hasil jar test dengan dosis koagulan yang berbeda 


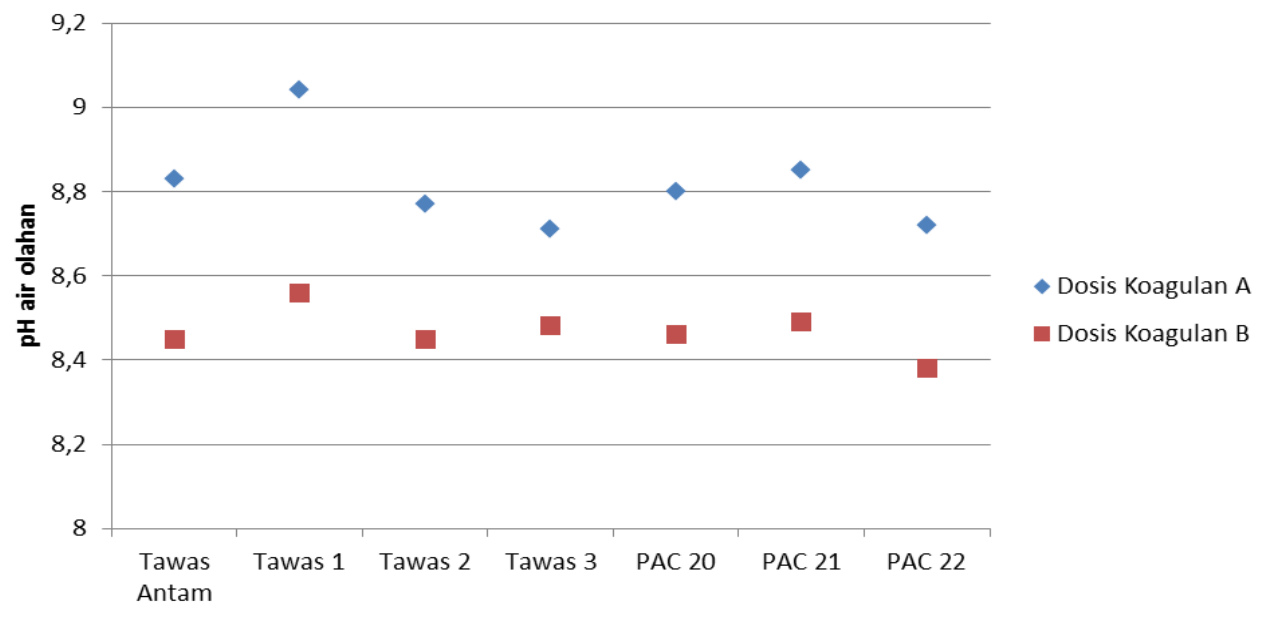

Gambar 4. Perbandingan $\mathrm{pH}$ hasil jar test dengan dosis koagulan yang berbeda

Standar baku mutu turbidity untuk air limbah buangan adalah $<25$ NTU. Sedangkan baku mutu $\mathrm{pH}$ untuk air limbah bagi kegiatan penambangan bijih emas dan atau tembaga adalah 6-9 (Kepmen LH Nomor 202 Tahun 2004). Air limbah industri yang belum terolah dan memiliki $\mathrm{pH}$ di luar rentang di atas akan mengubah $\mathrm{pH}$ air sungai dan dapat mengganggu kehidupan organisme di dalamnya (El Karamany, 2010). Oleh karena itu, $\mathrm{pH}$ air terolah dengan menggunakan koagulan skala laboratorium ini masih perlu diturunkan agar sesuai dengan standar yang seharusnya.

\section{Hasil Jar Test PAC Skala Pilot dan Koagulan PT Antam}

Agar dapat diaplikasikan ke skala komersial, PAC hasil penelitian skala laboratorium perlu ditingkatkan ke skala pilot untuk menguji kinerja produk dan proses pembuatan produk tersebut. Penelitian pembuatan PAC skala pilot ini dilakukan beberapa kali variasi percobaan. Setelah percobaan selesai, dilakukan jar test terhadap PAC hasil penelitian dan dibandingkan dengan hasil jar test koagulan yang digunakan PT Antam. Untuk mengetahui dosis penggunaan PAC, sebelumnya dilakukan diskusi dengan petugas yang menangani IPAL PT Antam.

Tabel 3 menunjukkan komposisi kimia PAC skala pilot yang digunakan pada jar test. PAC hasil penelitian tekMIRA ini memiliki 10,85$12,57 \% \mathrm{Al}_{2} \mathrm{O}_{3}, 11,24-12 \% \mathrm{Cl}, 2,66-3,62 \%$ $\mathrm{SO}_{4}$ dan $\mathrm{pH}$ sekitar 1,6 - 1,8, sedangkan PAC
Antam memiliki $1,785 \% \mathrm{Al}_{2} \mathrm{O}_{3}, \leq 0,0001 \%$ $\mathrm{Cl}$ serta $5,33 \% \mathrm{SO}_{4}$.

Dosis koagulan curah yang biasa digunakan di lapangan adalah $0,76 \mathrm{~kg} /$ ton limbah. Oleh karena itu, dosis awal yang digunakan untuk Jar Test ini adalah 0,76 g/L limbah. Dari hasil uji Jar Test dengan dosis 0,76 g/L ini, TSS yang dihasilkan dari air limbah terolah relatif sangat rendah yaitu 8,5 ppm dengan turbidity 7,85 NTU (koagulan Antam). Sedangkan dengan menggunakan PAC tekMIRA memberikan TSS sebesar 1,5-4 ppm dan turbidity 3,02-6,98 NTU). Oleh karena itu, dosis diturunkan lagi menjadi 0,684 g/L dan dilakukan uji Jar Test sebanyak dua kali yang menghasilkan TSS rata-rata sebesar 43,5 g/L dan turbidity 8,46 NTU (koagulan Antam). Sedangkan dengan menggunakan PAC tekMIRA menghasilkan TSS 36,67-54 g/L dan turbidity 4,16-6,2 NTU. Selanjutnya dosis diturunkan lagi menjadi 0,3 g/L air limbah (turun sekitar 56,14\%). TSS air limbah terolah yang diperoleh adalah sebesar 48,67 g/L (Antam) dengan turbidity 5,37 NTU. Sedangkan dengan menggunakan PAC tekMIRA menghasilkan TSS antara 29,67 45,67 g/L dan turbidity antara 2,93-4,61. Untuk membandingkan pemakaian koagulan saja dengan campuran koagulan dan flokulan, maka dicoba juga uji jar test dengan dosis 0,3 g koagulan/L dicampur dengan 0,3 g flokulan /L. Hasil yang diperoleh adalah TSS air terolah dengan campuran koagulan dan flokulan sebagai berikut: TSS untuk air terolah $44 \mathrm{~g} / \mathrm{L}$ (Antam) dan 37,67-42,67 g/L (PAC tekMIRA). Jadi dengan pemakaian flokulan terdapat 
perbaikan nilai TSS dari 48,67 g/L menjadi 44 g/L. Sedangkan untuk PAC tekMIRA, dengan pemakaian flokulan nilai TSS yang diperoleh lebih tinggi dibandingkan tanpa menggunakan flokulan (untuk PAC 10 dan PAC 11), namun untuk PAC 11 adanya campuran flokulan ke dalam PAC memberi pengaruh positif terhadap TTS yaitu 42,67 g/L dibandingkan dengan 45,67 g/L.

Dari serangkaian uji Jar Test tersebut, terlihat bahwa PAC hasil percobaan tekMIRA lebih baik dibandingkan dengan koagulan curah yang selama ini digunakan oleh IPAL di Pongkor. PAC tekMIRA yang kualitasnya paling baik adalah PAC 11 diikuti oleh PAC 10 dan PAC 9. Dari uji jar test di atas, dapat disimpulkan bahwa penggunaan dosis $0,3 \mathrm{~g} / \mathrm{L}$ limbah masih menghasilkan air terolah dengan TSS di bawah 50 ppm (digunakan sebagai standar di IPAL Pongkor). Flokulan yang digunakan pada jar test disesuaikan dengan dosis yang digunakan di lapangan yaitu sekitar 0,33 $\mathrm{g} / \mathrm{L}$ air limbah.

Apabila dibandingkan dengan hasil penelitian (Awad, Li and Hongtao, 2013) penggunaan PAC (dosis $30 \mathrm{mg} / \mathrm{L}$ ) untuk pengolahan limbah yang semula memiliki turbidity 46,8 NTU dapat diturunkan menjadi 1,8 NTU (efisiensi penurunan 96,2\%) pada $\mathrm{pH} 7,3$.

Tabel 7 dan Gambar 5 menunjukkan nilai turbidity air limbah terolah hasil jar test dengan menggunakan PAC hasil penelitian tekMIRA dibandingkan dengan PAC Antam untuk berbagai dosis. Telihat bahwa PAC
tekMIRA dapat menjernihkan air lebih baik dibandingkan dengan PAC yang digunakan oleh PT Antam. Nilai turbidity air limbah awal 130,74 NTU setelah diolah dengan PAC 9, PAC 10, dan PAC 11 menggunakan dosis koagulan 0,3 g/L berturut-turut menghasilkan turbidity 4,61, 3,54, dan 2,93 NTU atau memberikan persen penurunan turbidity berturut-turut 96,47, 97,29, dan 97,76\%, sedangkan dengan menggunakan PAC Antam memberikan nilai turbidity 5,37 NTU atau menghasilkan persen penurunan turbidity hanya sebesar 95,89\%,. Nilai turbidity air limbah terolah terkecil dihasilkan dari penggunaan PAC 11. Bila dikaitkan dengan standar air buangan industri yang mempersyaratkan turbidity maksimum 25 NTU, maka baik PAC Antam maupun PAC tekMIRA semuanya sudah menghasilkan turbidity air limbah terolah yang sudah memenuhi syarat dengan tingkat penurunan turbidity 90,59-96,43\% (Antam) dan 92,79$97,77 \%$ (tekMIRA). Data tersebut lebih baik bila dibandingkan dengan hasil penelitian (Astuti dan Darnoto, 2009) yang mengolah limbah leachate dengan turbidity awal 2190,2 NTU, setelah ditambah PAC turun menjadi 528,2 NTU (penurunan turbidity 75,88\%). Hal ini mungkin disebabkan oleh turbidity awal yang lebih tinggi dibandingkan dengan yang digunakan untuk PAC Antam maupun tekMIRA. Sementara hasil penelitian Rinaldi (2009) PAC dapat menurunkan turbidity dari 166 menjadi 4,60 NTU (penurunan turbidity sebesar $96.50 \%$ ) yang berarti masuk rentang data penggunaan PAC tekMIRA.

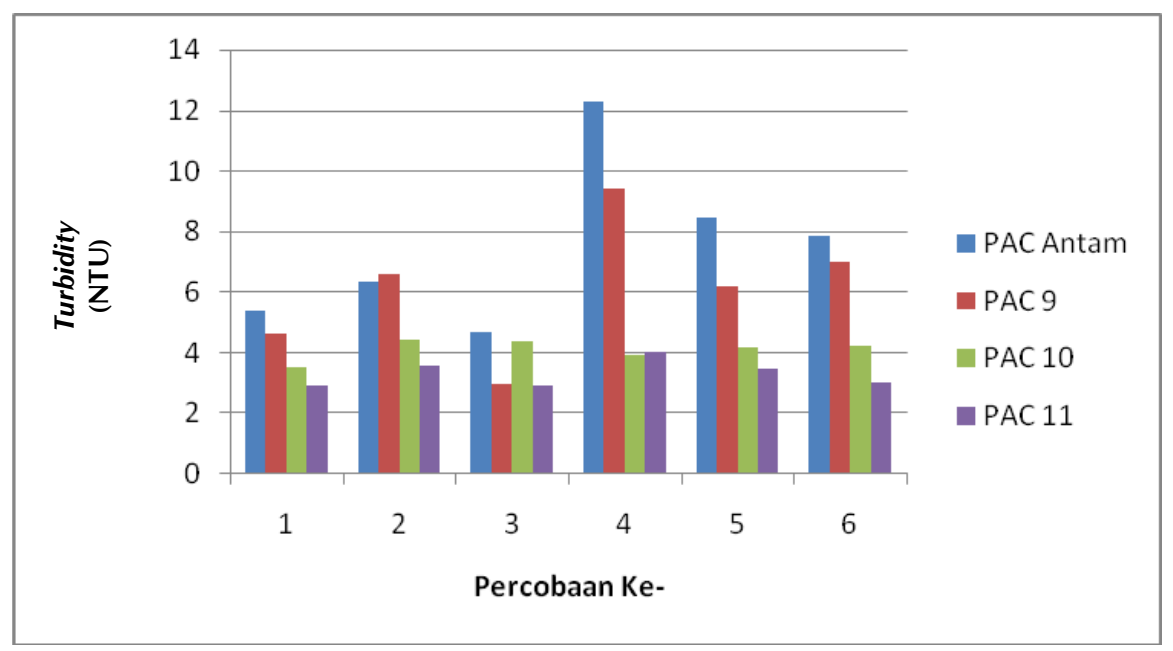

Gambar 5. Perbandingan turbidity air terolah dengan menggunakan PAC tekMIRA dan PAC Antam 


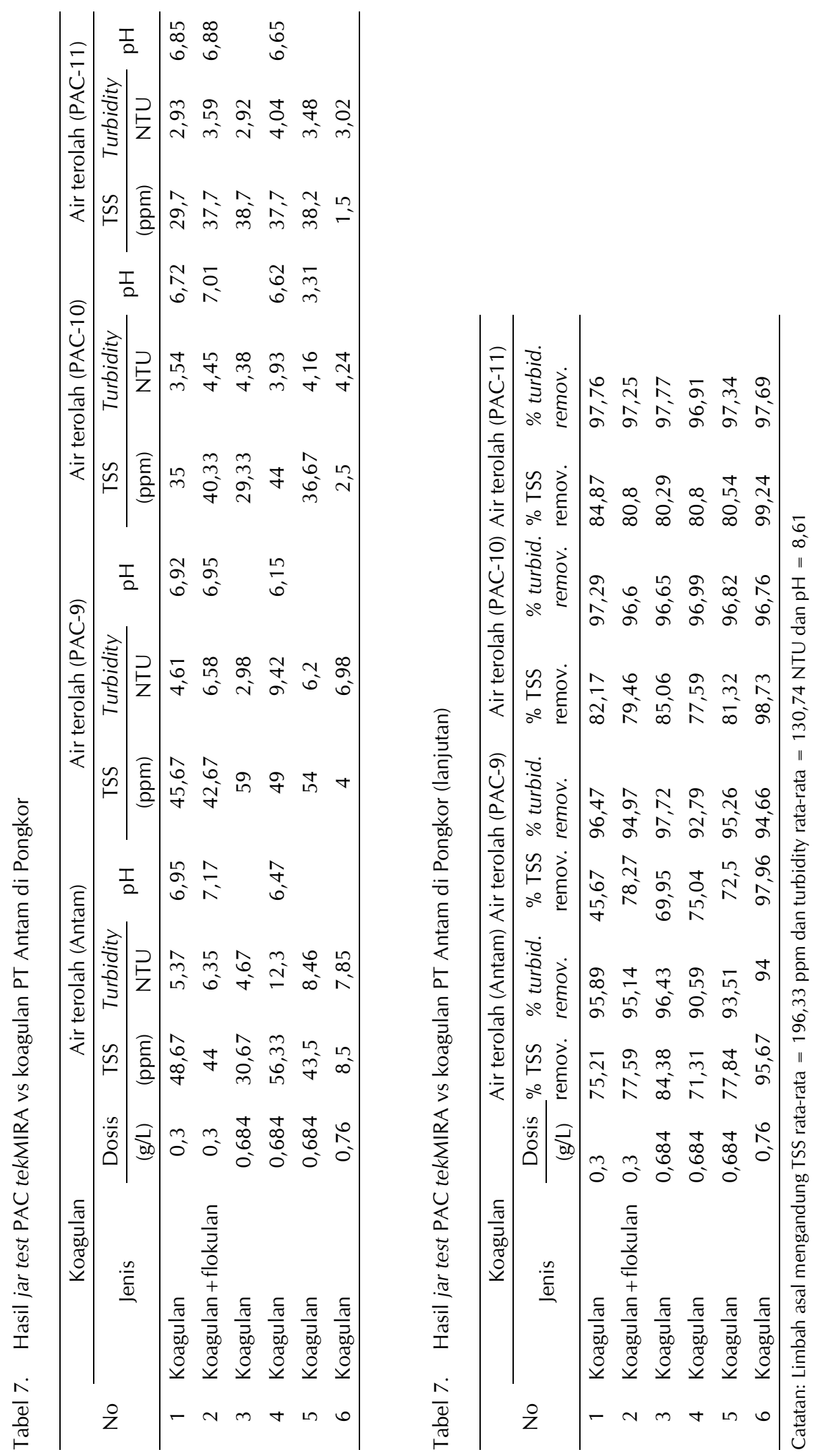


Sedangkan hasil penelitian Susanti, Muhdarina dan Amri (2016) memberikan persen penurunan turbidity sedikit lebih baik yaitu $98,11 \%$ untuk limbah gambut yang memiliki turbidity 128 NTU dengan menggunakan berat PAC 2 g (volume 0,5 gram) untuk volume limbah 0,5 L. Hal ini mungkin disebabkan oleh turbidity awal yang lebih rendah.

Selain turbidity, karakteristik air yang perlu diukur adalah total suspended solid (TSS). TSS adalah residu dari padatan total yang tertahan oleh saringan dengan ukuran partikel $2 \mu \mathrm{m}$ atau lebih besar dari ukuran partikel koloid. Semakin kecil nilai TSS berarti air terolah semakin jernih. Dari nilai TSS yang diperoleh, PAC 11 dan PAC 10 memberikan nilai TSS yang relatif lebih rendah dari PAC lainnya. Seperti percobaan sebelumnya jar test ini juga dilakukan dengan beberapa variasi dosis koagulan untuk mengetahui pengaruh jumlah dosis terhadap hasil jar test. Jumlah dosis yang digunakan yaitu 0,3 g/L, 0,684 $\mathrm{g} / \mathrm{L}$ dan 0,76 $\mathrm{g} / \mathrm{L}$. Hasil yang diperoleh dapat dilihat pada Tabel 7 dan Gambar 6. Telihat bahwa PAC tekMIRA dapat menurunkan TSS dalam air lebih baik dibandingkan dengan PAC yang digunakan oleh PT Antam. Nilai TSS air limbah awal 196,33 g/L setelah diolah dengan PAC 9, PAC 10, dan PAC 11 menggunakan dosis koagulan $0,3 \mathrm{~g} / \mathrm{L}$ berturut-turut menghasilkan TSS 45,67, 35, dan 29,7 g/L atau memberikan persen penurunan TSS berturut-turut 76,74, 82,17, dan 84,87\%, sedangkan dengan menggunakan PAC Antam memberikan nilai TSS 48,67 g/L atau menghasilkan persen penurunan TSS hanya sebesar 75,21\%,. Nilai TSS air limbah terolah terkecil dihasilkan dari penggunaan PAC 11. Bila dikaitkan dengan standar air buangan industri yang mensyaratkan TSS maksimum 50 ppm, maka baik PAC Antam maupun PAC tekMIRA semuanya sudah menghasilkan TSS air limbah terolah yang sudah memenuhi syarat dengan tingkat penurunan TSS 71,3195,67\% (Antam) dan 69,95-99,24\% (tekMIRA). Data penurunan TSS tersebut apabila dirata-ratakan baik untuk PAC Antam maupun PAC tekMIRA masih lebih baik bila dibandingkan dengan data yang dihasilkan oleh Yuanita (2015) yang mengolah limbah cair industri penyamakan kulit yang hanya dapat menurunkan TSS dari $60,67 \mathrm{~g} / \mathrm{L}$ menjadi 8,67 g/L (persen penurunan 85,73\%) dengan menggunakan dosis PAC $1 \mathrm{~g} / \mathrm{L}$.

Demikian juga bila dibandingkan dengan hasil penelitian (Yustinawati, Nirwana dan $\mathrm{Hs}$, 2014), yang menggunakan PAC dengan konsentrasi $6000 \mathrm{~g} / \mathrm{L}$ untuk menurunkan kadar TSS dari Limbah Lumpur Pemboran Sumur Minyak mereka dapat menurunkan TSS dari 2672 g/L menjadi 427,52 g/L atau dengan efisiensi sebesar $84 \%$, maka hasil penelitian ini lebih baik.

Demikian juga bila dibandingkan dengan hasil penelitian Kartika (2015), yang mengolah limbah laundry dengan TSS awal $350 \mathrm{~g} / \mathrm{L}$ dapat diturunkan menjadi 23,33 g/L dengan menggunakan dosis PAC 150 ppm (penurunan TSS sebesar 93,27\%).

Untuk PAC Antam, dosis yang digunakan cukup berpengaruh pada hasil jar test, demikian juga dengan PAC 9. Akan tetapi untuk PAC 10 dan 11, dosis tidak berpengaruh signifikan. Walaupun menggunakan dosis 2 kali lebih banyak dibandingkan dengan dosis sebelumnya, turbidity air terolah tidak berubah secara signifikan. Dengan pemakaian yang sedikit, PAC 11 dan PAC 10 dapat menghasilkan air terolah yang memiliki total suspended solid yang rendah. PAC dengan kemampuan terbaik adalah PAC 11. $\mathrm{pH}$ air terolah hasil jar test ini telah sesuai dengan $\mathrm{pH}$ netral (7) sehingga telah layak bagi lingkungan. $\mathrm{pH}$ air yang sangat tinggi tidak dapat dibuang ke lingkungan karena dapat mencemari lingkungan seperti halnya limbah detergen yang bersifat basa dapat merusak keseimbangan ekosistem air. Untuk menghindari hal tersebut, maka perlu dilakukan pengolahan lebih lanjut agar air ini tidak lagi berdampak buruk bagi lingkungan.

Gambar 8 menunjukkan $\mathrm{pH}$ air terolah dengan menggunakan PAC Antam dan PAC tekMIRA hasil penelitian skala pilot. Terlihat bahwa nilai $\mathrm{pH}$ air terolah berkisar antara 6 s/d 7,2 yang telah memenuhi standar baku mutu air buangan limbah industri. 


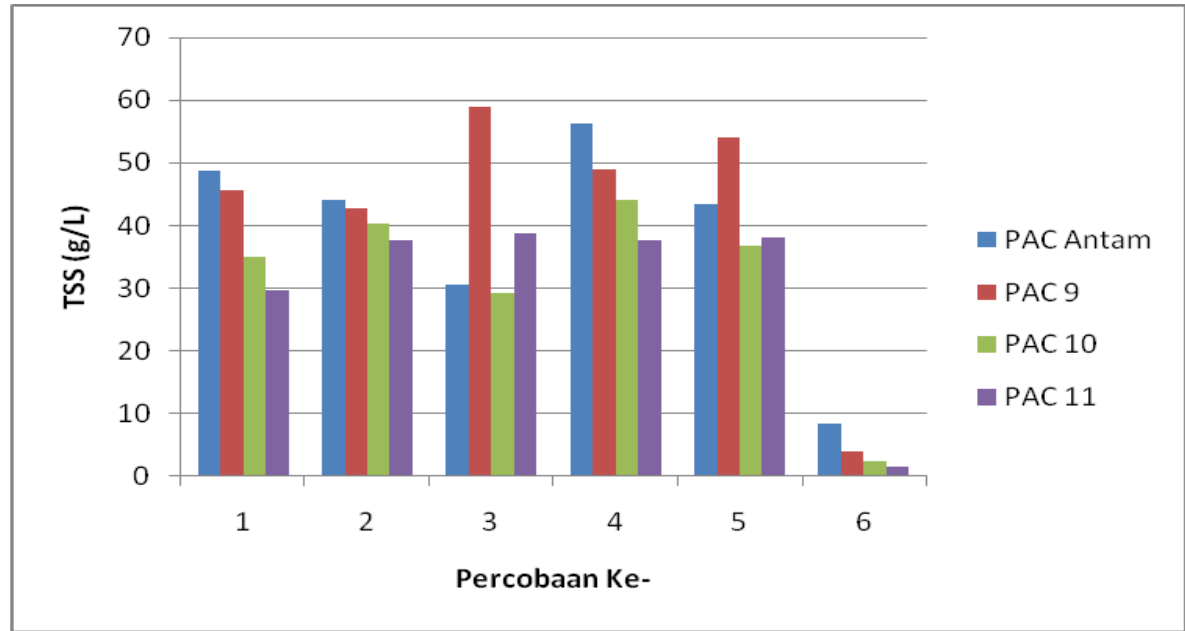

Gambar 6. Perbandingan suspended solid air terolah dengan menggunakan PAC tekMIRA dan PAC Antam

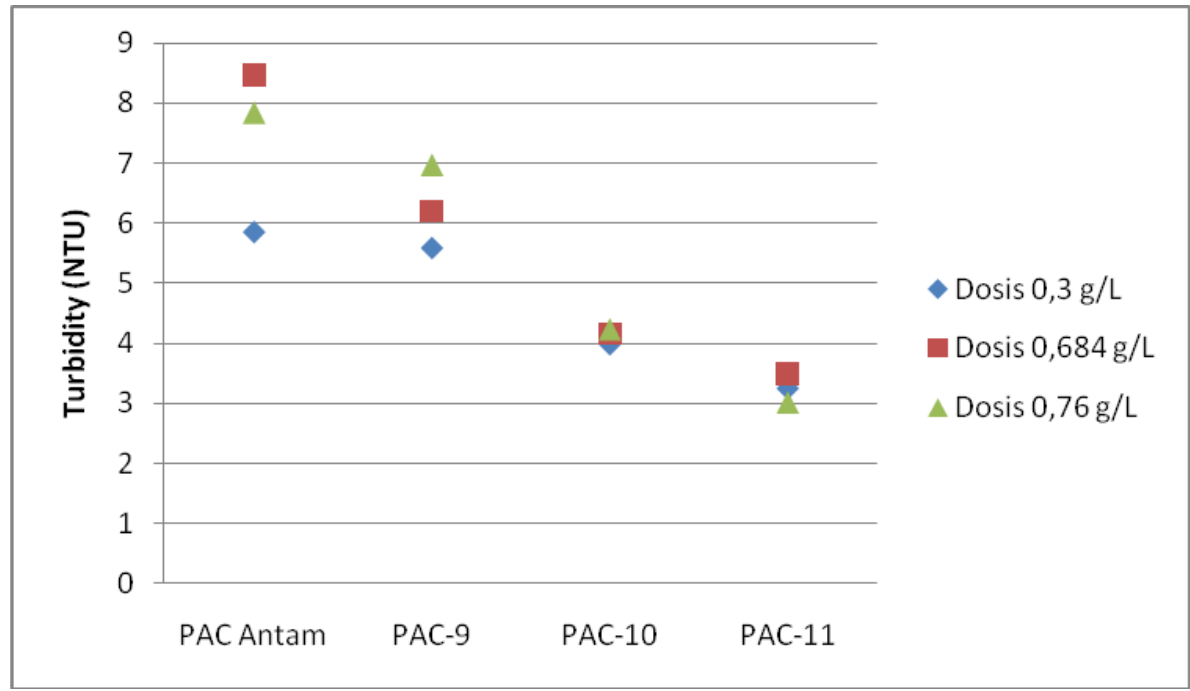

Gambar 7. Perbandingan turbidity air terolah dengan menggunakan PAC tekMIRA dan PAC Antam

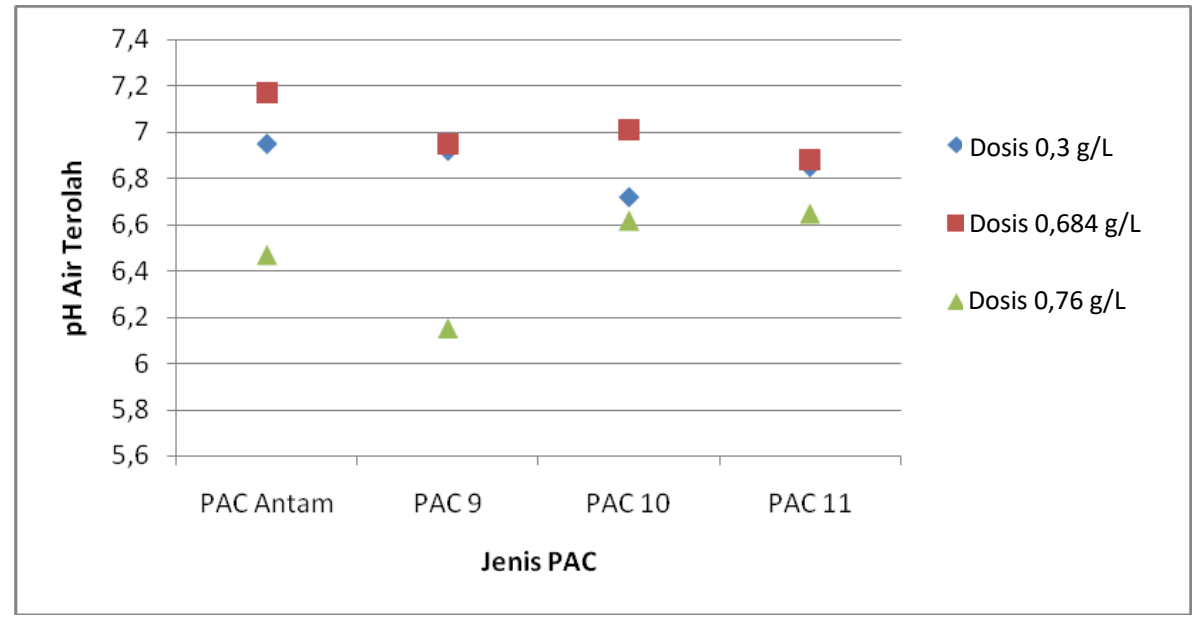

Gambar 8. pH Air terolah hasil jar test 


\section{KESIMPULAN DAN SARAN}

\section{Kesimpulan}

Berdasarkan hasil Jar Test yang telah dilakukan dapat disimpulkan beberapa hal sebagai berikut:

- PAC dan Tawas hasil penelitian skala laboratorium oleh Puslitbang tekMIRA memberikan efisiensi penurunan turbidity air limbah terolah yang lebih tinggi dibandingkan yang diperoleh dengan koagulan PT Antam. Tawas yang memiliki kemampuan paling baik untuk menjernihkan air limbah adalah Tawas 3 dengan komposisi kimia $17,73 \% \quad \mathrm{Al}_{2} \mathrm{O}_{3}$, $10,3 \% \quad \mathrm{SO}_{4}, \quad 12,96 \% \quad \mathrm{H}_{2} \mathrm{O}$. Air limbah terolah yang dihasilkan dengan Tawas 3 ini memiliki nilai turbidity yang lebih rendah dibandingkan jika diolah dengan tawas yang biasa digunakan oleh PT Antam.

- PAC hasil penelitian skala pilot yang memiliki kemampuan paling baik adalah PAC 11 dengan komposisi kimia 12,57\% $\mathrm{Al}_{2} \mathrm{O}_{3}, 12 \% \mathrm{Cl}^{-}$serta $3,62 \% \mathrm{SO}_{4}{ }^{2-}$. PAC 11 ini memberikan efisiensi penurunan turbidity dan TSS air limbah masingmasing 97,69\% dan 99,24\%, sedangkan koagulan PT Antam hanya 94\% dan 95,67\% dengan dosis PAC 0,76 g/L, atau mampu menurunkan turbidity air limbah dari semula 130,74 NTU menjadi 2,93 4,04 NTU (PAC tekMIRA), jauh lebih baik dibandingkan dengan PAC yang digunakan oleh PT Antam yang hanya mampu menurunkan turbidity air limbah sampai 4,67-12,3 NTU.

- PAC hasil penelitian skala pilot plant telah mampu menurunkan $\mathrm{pH}$ air limbah menjadi $\mathrm{pH}$ normal sehingga tidak membahayakan lingkungan.

\section{Saran}

Koagulan (PAC dan Tawas) hasil penelitian Puslitbang tekMIRA ini dapat menjadi solusi baru bagi pengolahan air limbah baik di industri maupun di lingkungan masyarakat. Untuk itu, perlu adanya pengembangan dan tindak lanjut nyata terhadap penelitian ini agar dapat dilanjutkan ke skala komersial sehingga manfaatnya dapat segera dirasakan.

\section{DAFTAR PUSTAKA}

Altenor, S. and Gaspard, S. (2014) "Chapter 1. Biomass for Water Treatment: Biosorbent, Coagulants and Flocculants," in Biomass for Sustainable Applications: Pollution Remediation and Energy. The Royal Society of Chemistry, pp. 1-45. doi: 10.1039/9781849737142-00001.

Astuti, D. and Darnoto, S. (2009) "Pengaruh penambahan poly aluminium chloride (PAC) terhadap tingkat kekeruhan, warna, dan total suspended solid (TSS) pada leachate (air lindi) di TPAS Putri Cempo Mojosongo Surakarta," Jurnal Kesehatan, 2(2), pp. 179184. Available at: https://publikasiilmiah.ums.ac.id/handle/116 17/2086.

Awad, M., Li, F. and Hongtao, W. (2013) "Application of natural clays and poly aluminium chloride (PAC) for wastewater treatment," International Journal of Research and Reviews in Applied Sciences, 15(2), pp. 287-291. Available at: http://www.arpapress.com/Volumes/Vol15lss ue2/IJRRAS_15_2_19.pdf.

Burgess, J., Meeker, M., Minton, J. and O'Donohue, M. (2015) “International research agency perspectives on potable water reuse," Environmental Science: Water Research \& Technology. The Royal Society of Chemistry, 1(5), pp. 563-580. doi: 10.1039/C5EW00165J.

Gebbie, P. (2001) "Using polyaluminium cogulants in water treatment," in 64 th Annual Water Industry Engineers and Operators' Conference. Bendigo: Australian Water and Wastewater Association, pp. 3947. Available at: http://citeseerx.ist.psu.edu/viewdoc/downloa $\mathrm{d}$ ?doi $=10.1 \cdot 1.517 .5307 \&$ rep $=$ rep $1 \&$ type $=$ pdf.

Haydar, S. and Aziz, J. A. (2009) "Coagulationflocculation studies of tannery wastewater using combination of alum with cationic and anionic polymers," Journal of Hazardous Materials, 168(2-3), pp. 1035-1040. doi: 10.1016/j.jhazmat.2009.02.140.

Husaini, H., Suganal, S., Sariman, S. and Ramanda, Y. (2016) "Pembuatan PAC cair dari alumina hidrat pada skala laboratorium," Jurnal Teknologi Mineral dan Batubara, 12(2), pp. 93-103. Available at: http://jurnal.tekmira.esdm.go.id/index.php/m inerba/article/view/98. 
El Karamany, H. (2010) "Study for industrial wastewater treatment using some coagulants," in Fourteenth International Water Technology Conference, IWTC 14 2010. Cairo: Water Technology Association (WTA), pp. 283-291. Available at: http://www.iwtc.info/2010_pdf/05-02.pdf.

Kartika, R. Y. (2015) Keefektifan dosis koagulan poly aluminium chloride (PAC) dalam menurunkan kadar total suspended solid (TSS) air limbah laundry. Universitas Muhamadiyah Surakarta. Available at: http://eprints.ums.ac.id/35447/.

Margaretha, Mayasari, R., Syaiful and Subroto (2012) "Pengaruh kualitas air baku terhadap dosis dan biaya koagulan aluminium sulfat dan poly aluminium chloride," Jurnal Teknik Kimia, 18(4), pp. 21-30. Available at: http://jtk.unsri.ac.id/index.php/jtk/article/vie w/30.

Mose, Y. (2014) Penerapan model pembelajaran predict-observe-explain (POE) pada materi koloid untuk meningkatkan keterampilan berpikir kritis dan keterampilan proses sains siswa. Universitas Pendidikan Indonesia. Available at: http://repository.upi.edu/7289/.

Nansubuga, I., Banadda, N., Babu, M., Verstraete, W. and Van de Wiele, T. (2013) "Effect of polyaluminium chloride water treatment sludge on effluent quality of domestic wastewater treatment," African Journal of Environmental Science and Technology, 7(4), pp. 145-152. doi: 10.5897/AJEST12.194.

Rinaldi, D. P. (2009) Pemanfaatan limbah industri logam aluminium sebagai bahan baku polialuminium klorida. Institut Pertanian Bogor. Available at: http://repository.ipb.ac.id/bitstream/handle/1 23456789/12493/G09dpr abstract.pdf;jsessi onid = AA8600364C57F018EC9098E714204 $46 \mathrm{~B}$ ? sequence $=1$.

Rusdi, Sidi, P. and Pratama, R. (2014) "Pengaruh konsentrasi dan waktu pengendapan biji kelor terhadap $\mathrm{pH}$, kekeruhan dan warna air Waduk Krenceng," Jurnal Integrasi proses, 5(1), pp. 46-50. Available at: http://jurnal.untirta.ac.id/index.php/jip/article /view/34.
Susanti, R., Muhdarina and Amri, T. A. (2016) Pemanfaatan koagulan cair PAC dari limbah aluminium foil kemasan susu: Efek variasi massa limbah. Universitas Riau. Available at: https://repository.unri.ac.id/xmlui/bitstream/h andle/123456789/8354/jurnal Rita Susanti1. pdf? sequence $=1$ \&isAllowed $=y$.

Wang, J., Song, J., Lu, J. and Zhao, X. (2014) "Comparison of three aluminum coagulants for phosphorus removal," Journal of Water Resource and Protection, 6(10), pp. 902908. doi: 10.4236/jwarp.2014.610085.

Water New Zealand (2013) Standard for the supply of polyaluminium chloride for use in water treatment. 2nd Ed. Wellington: Water New Zealand. Available at: https://www.waternz.org.nz/Attachment?Acti on $=$ Download\&Attachment $\_$id $=117$.

Yuanita, Y. A. (2015) Keefektifan dosis PAC (Poly Aluminium Chloride) terhadap penurunan kadar TSS (Total Suspended Solid) limbah industri penyamakan kulit Magetan. Universitas Muhammadiyah Surakarta. Available http://eprints.ums.ac.id/39281/1/NASKAH PUBLIKASI.pdf.

Yustinawati, Nirwana and Hs, I. (2014) "Efektifitas poly aluminium chloride (PAC) pada pengolahan limbah lumpur pemboran sumur minyak," Jurnal Online Mahasiswa Fakultas Teknik Universitas Riau, p. 10. Available at: https://www.neliti.com/id/publications/2022 84/efektifitas-poly-aluminium-chloride-pacpada-pengolahan-limbah-lumpur-pemborans.

Zhou, F., Hu, B., Cui, B., Liu, F., Liu, F., Wang, W., Liu, Y., Lu, R., Hu, Y., Zhang, Y. and $\mathrm{Wu}$, J. (2014) "Preparation and characteristics of polyaluminium chloride by utilizing fluorine-containing waste acidic mother liquid from clay-brine synthetic cryolite process," Journal of Chemistry, 2014, pp. 1-7. doi: 10.1155/2014/274126.

Zouboulis, A. I. and Tzoupanos, N. (2010) "Alternative cost-effective preparation method of polyaluminium chloride (PAC) coagulant agent: Characterization and comparative application for water/wastewater treatment," Desalination, 250(1), pp. 339-344. doi: 10.1016/j.desal.2009.09.053. 
